ЕЖОВ Дмитрий Александрович - кандидат политических наук, доцент; доцент департамента политологии и массовых коммуникаций Финансового университета при Правительстве РФ (125993, Россия, г. Москва, Ленинградский пр-кт, 49; president@lenta.ru)

\title{
К ОЦЕНКЕ ПОЛИТИЧЕСКОГО ПОТЕНЦИАЛА НОВЫХ ПАРТИЙНЫХ ПРОЕКТОВ В КОНТЕКСТЕ АКТУАЛИЗАЦИИ ШОУ-ТЕХНОЛОГИЙ
}

Аннотация. В статье оценивается политический и электоральный потенциал партийных проектов, анонсированных в конце 2019 - начале 2020 г. Отдельное внимание уделено перспективам вновь создаваемых политических партий в контексте тенденции шоуизации выборов, практически проявляющейся в интеграции в их деятельность медийных персон. Хотя усиление тенденции к шоуизации выборов вполне очевидно, автор подчеркивает, что политический потенциал новых партийных проектов балансирует на уровне от относительно низкого до крайне низкого. В своих суждениях автор исходит из предположения, что новые партийные проекты направлены на сегментацию скептически настроенного электората.

Ключевые слова: партийные проекты, политические партии, выборы, шоуизация, шоу-технологии

B преддверии предстоящих выборов в Государственную думу Федерального собрания РФ 8-го созыва, которые предположительно состоятся в 2021 г., наблюдается активность в области создания новых партийных проектов и ребрендинга зарегистрированных партий путем интеграции в их деятельность медийных персон. В качестве исследовательской цели рассматривается оценка политического потенциала вновь создаваемых политических партий в условиях трансформирующейся политико-властной конфигурации. Поставленная цель достигается посредством анализа актуальных тенденций партийного строительства в современной России. Автор исходит из гипотезы, что конструирование новых партийных проектов в рамках реализуемого сценария способствует увеличению доли шоу-технологий в избирательном процессе и направлено на сегментацию скептически настроенного электората посредством производства акцента на эффекты массовизации и шоуизации.

За последние месяцы в России было объявлено о создании общественного движения писателя 3. Прилепина «За правду», партии «Зеленая альтернатива»; о желании создать партию заявили экс-депутат Госдумы от фракции ЛДПР Р. Худяков, владелец компании Faberlic А. Нечаев, один из создателей онлайн-игры World of Tanks В. Макаров, активист «Открытой России» депутат Липецкого областного совета О. Хомутинников; с инициативой создания партии «Сильные женщины» во главе с народной артисткой РФ певицей Валерией выступил ее супруг и продюсер И. Пригожин. Большая часть приведенных примеров в целом отражает тренды шоуизации и массовизации выборов, проанализированные нами в предыдущих исследованиях [Ежов 2018]. Рассмотрим проявления указанных тенденций, сконцентрировавшись на отдельных наиболее характерных примерах из актуальной практики конструирования партийных проектов.

1 февраля 2020 г. в Москве прошел учредительный съезд партии «За правду», созданной на основе одноименного общественного движения. Организация позиционирует себя как национал-патриотическую партию и в проектируемом партийном спектре стремится занять нишу в консервативном сегменте, делая при этом акцент на том, что в качестве идеологической основы ее функционирования выступает критика либерализма. Лицами движения, наряду с уже упоминавшимся писателем 3. Прилепиным, являются политолог 
А. Казаков, театральный режиссер Э. Бояков, основатель рок-группы «Агата Кристи» В. Самойлов. Также в числе сторонников движения оказались актер и временно отстраненный от служения по собственному желанию священник Русской православной церкви И. Охлобыстин, рок-певица Ю. Чичерина, а также известный американский актер, получивший гражданство РФ, специальный представитель МИДа России по гуманитарным связям России и США С. Сигал. Примечательно, что одна из центральных тем в партийной риторике - судьба Донецкой народной республики (ДНР), которая является объединяющим элементом для большинства лиц партии. В частности, на официальном сайте движения прямо говорится, что «Донбасс должен вернуться в Россию». Политический потенциал рассматриваемого проекта как самостоятельного и долгосрочного на данном этапе относительно низок, несмотря на отсутствие серьезных конкурентов в соответствующей идеологической нише, за счет тяготения к популистской риторике. Можно говорить и о том, что «За правду» является не чем иным, как очередной попыткой реинкарнации политического игрока на национал-патриотическом поле (вследствие того, что проект «Партия «Родина» в электоральном отношении оказался малоэффективным в современных политических реалиях). Впрочем, высокая концентрация среди кандидатов на выборах медийных персон и представителей шоу-бизнеса, ассоциируемых с партией, может привести к определенному числу их побед в одномандатных округах.

10 марта 2020 г. состоялся учредительный съезд политической партии «Зеленая альтернатива», вносящей в электоральный дискурс экологическую повестку. Манифест партии построен на принципе комбинации эффектных слоганов, в совокупном восприятии создающих у потенциального избирателя состояние страха за будущее («Природа России отравлена», «Страна плачет», «Последствия пугают» и пр.). По большому счету, появление новой экологической партии в России вполне ожидаемо по причине актуализации соответствующей повестки на глобальном уровне. Однако, несмотря на чрезвычайное внимание к экологии в современном мире, в частности, подтверждаемое и тем фактом, что человеком 2019 года, по версии американского журнала Time, признана шведская экоактивистка Г. Тунберг, партии экологической направленности в России исторически не имели широкой электоральной базы. Апелляция к шоу-технологиям в позиционировании «Зеленой альтернативы» сводится к намерению выдвинуть в качестве кандидата на выборах в Государственную думу художника Васю Ложкина (А. Куделина) - яркого представителя примитивизма в искусстве, преимущественно изображающего на своих картинах алкоголиков, зайцев и котов.

Партийный проект «Сильные женщины», о создании которого объявлено в феврале 2020 г., ориентирован на защиту прав женщин и борьбу против домашнего насилия. С учетом того, что в качестве предполагаемого лидера будущей партии выступает известная певица Валерия (А. Перфилова), актуальность тренда на транзит звезд шоу-бизнеса в политику представляется более чем очевидной. Политический потенциал партии, по нашему убеждению, низок из-за относительно узкой электоральной базы. Успех в современной истории России из партий с созвучной предвыборной риторикой имела только партия «Женщины России», получившая в 1993 г. на выборах в федеральный парламент $8,13 \%$ голосов, благодаря чему удалось сформировать фракцию из 23 депутатов, двое из которых были избраны по одномандатным округам.

В начале 2020 г. была учреждена партия «Достойная жизнь», лидером которой стал бывший депутат Государственной думы РФ Р. Худяков. Для партии характерна популистская риторика в сочетании с элементами шоу-политики, 
что обусловливается как наличием в органах управления партии медийных персон (солист группы «Корни» А. Бердников, актер А. Клюквин, футболист Д. Кузнецов), так и личностью самого лидера. Так, общеизвестно, что в 2014 г. Р. Худяков заявил, что изображение Аполлона на купюре в 100 рублей является порнографическим и предложил изменить ее дизайн. Делать предположения о политическом потенциале партии представляется затруднительным по причине недостаточности информации ввиду отсутствия на ее сайте устава и программы, но мы склоняемся к целесообразности его рассмотрения на крайне низком уровне.

Отдельно следует отметить, что в феврале 2020 г. в Партию Роста вступил лидер группы «Ленинград», член Общественного совета по культуре при Государственной думе РФ С. Шнуров. Указанный факт свидетельствует о попытке персонального усиления уже существующей партийной структуры посредством внедрения в нее медийных лиц в преддверии федеральных выборов. Как известно, партия возникла в результате реорганизации правоцентристской партии «Правое дело» в 2016 г., и на сегодняшний день имеет всего лишь 8 мест в региональных парламентах по всей России. По состоянию на начало марта 2020 г. Партия Роста рассматривает кандидатуру С. Шнурова для выдвижения на довыборы депутатов Законодательного собрания Санкт-Петербурга по избирательному округу № 21. Полагаем, что пример Партии Роста может быть заимствован другими политическими партиями для усиления их электоральной базы.

В заключение отметим, что политический потенциал новых партийных проектов балансирует на уровне от относительно низкого до крайне низкого. В то же время усиление тенденции к шоуизации выборов представляется вполне очевидным. Гипотетически новые партии могут получить определенное число голосов скептически настроенной части электората, но с наибольшей долей вероятности такой исход ожидаем в одномандатных округах за счет фактора медийности выдвигаемых кандидатов. Это, в свою очередь, значительно затруднит формирование полноценных депутатских фракций и создаст предпосылки для вхождения избранных депутатов в более крупные из них по итогам комплектования депутатского корпуса Государственной думы 8-го созыва.

\section{Список литературы}

Ежов Д.А. 2018. Выборы в условиях шоуизации: технологии и социальные последствия. - Вестник Института социологии. № 25. С. 130-144.

\section{ON ASSESSING THE POLITICAL POTENTIAL OF NEW PARTY PROJECTS IN THE CONTEXT OF UPDATING SHOW TECHNOLOGIES}

Abstract. The article assesses the political and electoral potential of party projects announced in late 2019 - early 2020. Particular attention is paid to the prospects of the newly created political parties in the context of the trend of showization of elections, which is practically manifested in the integration of media persons in their activities. Although the growing tendency to showization of elections is obvious, the author emphasizes that the political potential of new party projects balances on the 
level from a relatively low to an extremely low one. In his judgments, the author assumes that new party projects are aimed at segmenting the skeptical electorate.

Keywords: party projects, political parties, elections, showization, show technologies

\section{УДК 327.8}

КУРАС Леонид Владимирович - доктор исторических наук, профессор, главный научный сотрудник отдела истории и культуры Центральной Азии Института монголоведения, буддологии и тибетологии СО РАН (670047, Россия, Республика Бурятия, г. Улан-Удэ, ул. Сахьяновой, 6, kuraslv@ yandex.ru)

\section{ДИССЕРТАЦИОННЫЕ СОЧИНЕНИЯ О МОНГОЛИИ КАК ПРОЯВЛЕНИЕ «МЯГКОЙ СИЛЫ» В РОССИЙСКО- МОНГОЛЬСКИХ ОТНОШЕНИЯХ}

\section{(на материалах диссертационного совета при ИМБТ СО РАН)}

Аннотация. С середины 80-х гг. XX в. «мягкая сила» стала важнейшим инструментом внешней политики и международных отношений ведущих держав. Лидерство в этом направлении принадлежит США. Этот механизм активно использовал и СССР по отношению к странам Варшавского договора и государствам по линии СЭВ. Наиболее полно механизм «мягкой силы» был задействован в отношениях с Монголией, причем не только в экономике, но и в социальной сфере - образовании, науке, искусстве, здравоохранении и ветеринарии.

Ключевые слова: СССР, МНР, «мягкая сила», Джозеф Най, социальная сфера

$\mathrm{B}$ последнее десятилетие понятие «мягкая сила» (soft power) стало важнейшей составляющей современных международных отношений. Честь введения этой категории в научный оборот принадлежит американскому политологу Джозефу Наю [Най 2004; 2006; Nye 2009]. Именно он справедливо полагает, что «мягкая сила» была и является сегодня наиболее действенным механизмом внешней политики ведущих мировых держав, способных добиваться желаемых результатов на основе привлекательности и добровольного участия, в отличие от «жесткой силы», которая предполагает силовое воздействие. Фактически благодаря Дж. Наю «мягкая сила» возведена рядом экспертов в доктрину, а США являются ее оплотом. Это объективно обусловлено тем, что США за последние 70 лет создали два «мирных» фактора своей мощи: господство над международной валютной системой и систему свободной торговли. Однако особую роль сыграл третий фактор - привлекательность, или soft power («мягкая сила»). «Действительно, ученые считают США кузницей нобелевских лауреатов, женщины - оплотом феминизма, болельщики поклоняются американскому спорту, киноманы - Голливуду, дети - Диснейленду, интернетчики - родине Интернета и глобальных социальных сетей» [Смирнов, Кохтюлина 2012: 24]. Не случайно в современном мировом сообществе существуют рейтинги фактора «мягкой силы» в ведущих странах мира (в числе разработчиков рейтингов находится и 